\title{
Factor VIII and antibody levels in plasma fractions prepared by cryoprecipitation
}

\author{
ANDREW POLLOCK \\ From the Haematology Department, Southern General Hospital, Glasgow
}

SYNOPSIS Most of the antibody activity of plasma was found to remain in the supernatant fraction following the preparation of factor-VIII-rich cryoprecipitates. The low level of antibody remaining in these cryoprecipitates indicated that they could safely be used as a source of factor VIII for replacement therapy. Washing the cryoprecipitates farther reduced their antibody titres without materially affecting their factor VIII content.

Following recent reports of success in preventing Rhesus isoimmunization in the early puerperium, by the injection of a high titre anti-D antibody (Woodrow, Clarke, Donohoe, Finn, McConnell, Sheppard, Lehane, Russell, Kulbe, and Durkin, 1965) it appears likely that this will become a standard procedure. Large amounts of high titre anti-D (anti-Rh) gamma globulin will be required and these will have to be obtained from deliberately immunized male volunteers.

This study was undertaken to determine whether plasma obtained from $\mathrm{Rh}$-sensitized individuals could be used to prepare an antihaemophilic globulin-rich cryoprecipitate without detracting from its usefullness as a source of anti-D.

\section{MATERIALS AND METHODS}

Two $20 \mathrm{ml}$ aliquots of blood were taken from $\mathrm{Rh}$ sensitized women using disposable plastic syringes. These were each added to $5 \mathrm{ml}$ acid citrate dextrose (ACD) in glass Universal containers and immediately centrifuged for 15 minutes at 3,000 r.p.m. at $4^{\circ} \mathrm{C}$ in an MSE Mistral centrifuge. The plasma was pooled and two $10 \mathrm{ml}$ aliquots were placed in Universal containers labelled 'cryoprecipitate' and 'cryoprecipitate (washed)', the remainder being labelled 'whole plasma'. The three samples were frozen at $-20^{\circ} \mathrm{C}$ for several hours after which the first two aliquots were transferred to a refrigerator and allowed to thaw out overnight at $4^{\circ} \mathrm{C}$. These samples were centrifuged at $4^{\circ} \mathrm{C}$ for $15 \mathrm{~min}$ at 3,000 r.p.m. and the supernatant plasma was decanted, pooled, and refrozen. One ml citrate-saline at $4{ }^{\circ} \mathrm{C}(1$ part $3.8 \%$ trisodium citrate and 9 parts $0.9 \% \mathrm{NaCl}$ ) was added to the cryo-

Received for publication 11 January 1968. precipitate' specimen which was immediately refrozen at $-20^{\circ} \mathrm{C}$ while $10 \mathrm{ml}$ citrate saline was added to the 'cryoprecipitate (washed)' specimen. This was mixed by gentle inversion without the precipitate being allowed to dissolve and centrifuged at $4^{\circ} \mathrm{C}$ and 3,000 r.p.m. for 15 minutes. The supernatant was discarded, a further $1 \mathrm{ml}$ citrate saline added, and the specimen refrozen. Within a week of preparation, the samples were thawed out at $37^{\circ} \mathrm{C}$ and factor VIII levels in both the cryoprecipitate specimens measured by a one-stage method (Hardisty and Macpherson, 1962). A pool of blood from at least five haematologically normal staff was taken as $100 \%$ normal. Antibody titres were then measured in all four specimens by the indirect antiglobulin (Coombs) test except where otherwise stated.

\section{RESULTS}

There was no reduction in antibody titre in the supernatant plasma after removal of the cryoprecipitate as compared with whole plasma (Table I).

The cryoprecipitates showed on average a four to eightfold drop in titre from the original plasma, and washing of the cryoprecipitate resulted in a further halving of the antibody level. These results were not corrected for volume changes, and as the cryoprecipitate had been reduced to one tenth of the volume of the original plasma it would appear that only about $1 \%$ of the antibody remained in the washed cryoprecipitate.

Factor VIII levels in the cryoprecipitate averaged $920 \%$ of normal, ie, equivalent to $92 \%$ in the volume of the original plasma. Washing the cryoprecipitate had little effect on the factor VIII level except in one instance (case 8). 
TABLE I

RESULTS FOR ANTIBODY TITRES AND FACTOR VIII

\begin{tabular}{|c|c|c|c|c|c|c|c|}
\hline \multirow[t]{2}{*}{ Patient } & \multirow[t]{2}{*}{ Antibody } & \multicolumn{4}{|l|}{ Antibody Titres } & \multicolumn{2}{|l|}{ Factor VIII (\%) } \\
\hline & & Whole Plasma & Supernatant & Cryoprecipitate & $\begin{array}{l}\text { Cryoprecipitate } \\
\text { (Washed) }\end{array}$ & Cryoprecipitate & $\begin{array}{l}\text { Cryoprecipitate } \\
\text { (Washed) }\end{array}$ \\
\hline 1 & $\begin{array}{l}\text { Anti D } \\
\text { Anti-D (papain) } \\
\text { Anti A (saline) }\end{array}$ & $\begin{array}{l}1 \text { in } 128 \\
1 \text { in } 64 \\
1 \text { in } 64\end{array}$ & $\begin{array}{l}1 \text { in } 256 \\
1 \text { in } 64 \\
1 \text { in } 64\end{array}$ & $\begin{array}{l}1 \text { in } 32 \\
1 \text { in } 16 \\
1 \text { in } 8\end{array}$ & - & & \\
\hline 2 & Anti $D$ (papain) & 1 in 64 & 1 in 64 & 1 in 4 & 1 in 2 & 860 & 800 \\
\hline 3 & Anti D (papain) & 1 in 8 & 1 in 4 & 1 in 2 & 1 in 1 & 1,000 & 1,120 \\
\hline 4 & Anti $\bar{D}$ (papain) & 1 in 4 & 1 in 4 & 1 in 2 & 1 in 1 & 850 & 680 \\
\hline 5 & Anti D & 1 in 4 & 1 in 2 & 1 in 1 & nil & 1,170 & 1,250 \\
\hline 6 & Anti D & 1 in 64 & 1 in 64 & 1 in 4 & 1 in 2 & 1,380 & 1,350 \\
\hline 7 & Anti D & 1 in 32 & 1 in 32 & 1 in 8 & 1 in 2 & 940 & 1,210 \\
\hline 8 & Anti Fy (a) & 1 in 2 & 1 in 2 & nil & nil & 720 & 200 \\
\hline 9 & Anti D & 1 in 128 & 1 in 256 & 1 in 32 & 1 in 8 & 830 & 910 \\
\hline 10 & Anti D & 1 in 16 & 1 in 16 & 1 in 4 & 1 in 2 & 386 & 435 \\
\hline 11 & Anti D & 1 in 16 & 1 in 32 & 1 in 8 & 1 in 4 & 1,130 & 1,190 \\
\hline 12 & Anti D & 1 in 16 & 1 in 32 & 1 in 8 & 1 in 8 & 830 & 570 \\
\hline
\end{tabular}

\section{DISCUSSION}

The experimental work of Finn, Clarke, Donohoe, McConnell, Sheppard, Lehane, and Kulke (1961) and Freda and Gorman (1962) showed that Rh (D)positive red cells could be injected into a D-negative recipient without producing sensitization if the recipient was protected by passive immunization with plasma containing a high titre of incomplete anti-D. Subsequent reports by these groups (Woodrow et al, 1965; Freda, Gorman, and Pollack 1965) have confirmed this work and shown that a high degree of clinical success can be achieved in preventing $\mathbf{R h}$ sensitization after pregnancy. Gorman, Freda, and Pollack (1965) and Clarke, Finn, Lehane, McConnell, Sheppard, and Woodrow (1966) have emphasized the superiority of gamma globulin, which can be given intramuscularly in small doses, to high titre whole plasma. If this approach is to be successful, large amounts of immune anti-D gamma globulin will be required and the only practical method of obtaining this is by plasmaphaeresis from deliberately immunized male volunteers, as the supply from $R h$-sensitized mothers will soon dry up if the treatment proves to be successful. A large amount of plasma will thus be available, and the complete utilization of this material is desirable.

The above results show that a factor-VIII-rich cryoprecipitate can be removed from the plasma without reducing the antibody titre in the residual plasma. Such cryoprecipitates are simple to prepare and highly effective in the treatment of haemophilia (Barrett, Israëls, and Burn, 1967; Pool and Shannon, 1965; Prentice, Breckenridge, Forman, and Ratnoff, 1967).

Regarding the possible danger to the recipient of a cryoprecipitate prepared from plasma with a high titre of anti-D, this could be resolved by reserving this material for $R h$ (D)-negative recipients. $A \overbrace{\mathbb{D}}$ similar system is practised in some centres, using fresh frozen plasma of the appropriate group for each recipient (Preston, 1967).

It is much more convenient, however, to be able to use plasma irrespective of group. Mollison (1961) has reviewed the literature relating to the ill effects of transfused antibodies, and evidence from several experimental sources and case reports indicates that $\Phi$ transfusion of about $400 \mathrm{ml}$ of plasma containing $\overrightarrow{\bar{\theta}}$ an incomplete anti-D titre of 256 is required to pro- $\frac{3}{3}$ duce appreciable destruction of red cells. Cryoprecipitates from 8 units of blood from donors with an anti-D titre of 1,000 or from 30 units with a titre of 256 would be required to reach this level, so that? this material could safely constitute at least part of the replacement therapy even in an $\mathrm{Rh}$ (D)-positive haemophiliac.

It is concluded that a factor-VIII-rich cryoprecipitate can easily be prepared from plasma without 군 detracting from its value as a source of antibody, $\rightarrow$ and that this can provide a valuable additional source of antihaemophilic globulin.

My thanks are due to the staff of the Department of $N$ Obstetrics at the Southern General Hospital for assistance in obtaining specimens, to $\mathrm{Dr} \mathrm{J}$. W. Whitelaw for advice and criticism, and to Miss Sarah Killen for technical assistance.

\section{REFERENCES}

Barrett, K. E., Israëls, M. C. G., and Burn, A. M. (1967). Lancet, 1 ,

Clarke, C. A., Finn, R., Lehane, D., McConnell, R. B., Sheppard, P. M., and Woodrow, J. C. (1966). Brit. med. J., 1, 213. 
Finn, R., Clarke, C. A. Donohoe, W. T. A., McConnell, R. B., Sheppard, P. M., Lehane, D., and Kulke, W. (1961). Ibid., 1, 1486.

Freda, V. J., and Gorman, J. G. (1962). Bull. Sloane Hosp. Wom., N.Y., 8, 147.

- - - - and Pollack, W. (1965). Lancet, 2, 690.

Gorman, J. G., Freda, V. J., and Pollack, W. (1965). Ibid., 2, 181.

Hardisty, R. M., and Macpherson, J. C. (1962). Thrombos. Diathes. haemorrh. (Stuttg.), 7, 215.
Mollison, P. L. (1961). Blood Transfusion in Clinical Medicine, 3rd ed. p. 495. Blackwell, Oxford.

Pool, J. G., and Shannon, A. E. (1965). New Engl. J. Med., 273, 1443. Prentice, C. R. M., Breckenridge, R. T., Forman, W. B., and Ratnoff, O. D. (1967). Lancet, 1, 457.

Preston, A. E. (1967). Ibid., 13, 42.

Woodrow, J. C., Clarke, C. A., Donohoe, W. T. A., Finn, R., McConnell, R. B., Sheppard, P. M., Lehane, D., Russell, S. H., Kulke, W., and Durkin, C. M. (1965). Brit. med. J., 1. 279.

\section{Reports and Bulletins prepared by the Association of Clinical Biochemists}

The following reports and bulletins are published by the Association of Clinical Biochemists. They may be obtained from The Administrative Office, Association of Clinical Biochemists, 7 Warwick Court, Holborn, London, W.C.1. The prices include postage, but airmail will be charged extra.

\section{SCIENTIFIC REPORTS}

1 Colorimeters with Flow Through Cells. A critical assessment of 4 instruments. 1965. P. M. G. BROUGHTON and C. RILEY. 13s. 6d.

2 Colorimeters. A critical assessment of 5 commercial instruments. 1966. P. M. G. BROUGHTON, C. RILEY, J. G. H. COOK, P. G. SANDERS, and H. BRAUNSBERG. $15 \mathrm{~s}$.

3 Automatic Dispensing Pipettes. An assessment of 35 commercial instruments. 1967. P. M. G. BROUGHTON, A. H. GOWENLOCK, G. M. WIDDOWSON, and K. A. AHLQUIST. 10s.

\section{TECHNICAL BULLETINS}

9 Determination of Urea by AutoAnalyzer. November 1966. RUTH M. HASLAM. 2s. 6d.
10 Filter Fluorimeters. A comparative list of 14 instruments. March 1967. HANNELORE BRAUNSBERG. 5s.

11 Determination of Serum Albumin by AutoAnalyzer using Bromocresol Green. October 1967. B. E. NORTHAM and G. M. WIDDOWSON. 2s. 6d.

12 Control Solutions for Clinical Biochemistry. February 1968. P. M. G. BROUGHTON. 2 s. 6 d.

13 An Assessment of the Technicon Type II Sampler Unit. March 1968. B. C. GRAY and G. K. MCGOWAN. 1s. 6 d.

14 Atomic Absorption Spectroscopy. An Outline of its Principles and a Guide to the Selection of Instruments. May 1968. J. B. DAWSON and P. M. G. BROUGHTON. 4s.

15 A Guide to Automatic Pipettes (2nd edition). June 1968. P. M. G. BROUGHTON. 5s. 